\title{
The Role of Counterparty Risk and Asymmetric Information in the Interbank Market*
}

\author{
Giuseppe Cappelletti ${ }^{\mathrm{a}}$ and Giovanni Guazzarotti ${ }^{\mathrm{b}}$ \\ aEuropean Central Bank \\ ${ }^{\mathrm{b}}$ Bank of Italy
}

We study the effect of counterparty risk on the ability of Italian banks to access the foreign unsecured interbank market during the sovereign debt crisis in the second half of 2011. With the onset of the crisis, interest rates in the Italian interbank market soared and foreign lending decreased significantly. To isolate the effect of the rise in counterparty risk, we compare the funding of Italian banks with that of foreign banks' branches and subsidiaries in Italy, which were presumably unaffected by the sovereign crisis insofar as they could count on the actual or potential support of their parent bank. We find that the rise in counterparty risk substantially decreased the probability of obtaining funds from foreign banks. When the analysis is restricted to Italian and foreign banks with relatively comparable asset compositions, the result holds. In addition, where safer banks or more stable lending relationships are involved, the effect is attenuated.

JEL Codes: G21, G28, C23, C24.

\section{Introduction}

Interbank markets are crucial to banks' liquidity management and to the transmission of monetary policy. They represent an important funding channel, and their functioning affects borrowing conditions

${ }^{*}$ We would like to thank Massimiliano Affinito, Fernando Alvarez, Antonio De Ninno, Antonio Di Cesare, Ginette Eramo, Roberto Felici, Domenico Giannone, Giorgio Gobbi, Florian Heider, David Marques Ibanez, Paolo Mistrulli, Enrico Sette, Tony O'Connor, seminar participants at the ECB, and two anonymous referees for helpful comments and suggestions. 
for households and firms. The recent financial crisis had a severe impact on the European money market, driving up interest rates and drastically reducing total transactions. A key feature of the crisis was the difficulty that the interbank market had in redistributing liquidity (see, for example, Brunnermeier 2009). One of the causes of this relative market failure was liquidity hoarding, as banks stopped lending due to precautionary motives, given the illiquidity of their assets (Allen, Carletti, and Gale 2009). A second channel of contagion was the increase in actual and perceived counterparty risk, especially in the segments more exposed to information asymmetry, namely unsecured and cross-border positions (Heider, Hoerova, and Holthausen 2009). While most studies of the crisis following the Lehman Brothers bankruptcy have examined its overall effects on the interbank market, we focus specifically on the impact of heightened counterparty risk due to the sovereign debt crisis.

In 2010-11, when the crisis started, financial intermediaries in Greece, Portugal, and - to a lesser extent, Spain and Italy 1 - had trouble raising wholesale funding and had to rely on central bank liquidity (Panetta et al. 2011). The increase in sovereign risk worsened banks' credit risk through several channels. First, losses on holdings of government debt weakened balance sheets, as banks are typically highly exposed to the debt of their own sovereigns. Second, higher sovereign risk reduced the value of collateral at banks' disposal for wholesale funding and central bank liquidity. Third, sovereign downgrades generally resulted in lower ratings for domestic banks, increasing their wholesale funding costs and potentially impairing their market access. Fourth, the deterioration in sovereign financial sustainability reduced the funding benefits that banks derive from implicit and explicit government guarantees.2

In July 2011 the spread between Italian and German ten-year government bonds jumped by 100 basis points and kept increasing through the end of the year, to over 4 percentage points. Adopting a

\footnotetext{
${ }^{1}$ These countries were also referred to as PIGS during the European debt crisis.

${ }^{2}$ Furthermore, sovereign tensions may have heightened investors' risk aversion, which in turn may have increased the premiums demanded on banks' securities, while the impact on capital markets may have reduced banks' fee and trading income, and the rise in sovereign yields may have crowded out private debt issuance.
} 
quasi-experimental methodology, we exploit the sharp, sudden rise in the yields on Italian sovereign debt, which can be deemed an exogenous increase in the riskiness of Italian banks: both low growth and high public debt are in fact long-standing features of the Italian economy, and the interbank market was not a direct source of instability for public debt.

This paper seeks to gauge the extent to which the increase in counterparty risk due to the sovereign crisis affected Italian banks' access to foreign bank lending. We study the unsecured segment of the market and restrict analysis to foreign lenders, who may have less precise credit information on Italian borrowers than domestic banks and may be more sensitive to changes in credit risk. The focus on foreign lenders also helps to disentangle counterparty risk from the liquidity hoarding channel, since foreign banks were affected less severely by the crisis and had no motive for precautionary liquidity hoarding.

To find a causal link between creditworthiness and funding, we exploit the differential impact of sovereign risk on foreign and domestic banks in Italy. In particular, to isolate the effect of a change in counterparty risk, we use difference-in-differences methodology to compare the borrowing capacity of Italian banks with that of peer banks that were not affected by the crisis. As a control group, we use the Italian branches and subsidiaries of foreign banks, on the assumption that the latter, being headquartered in countries where the increase in sovereign risk was much more moderate, were accordingly more sheltered from sovereign strains: foreign branches and subsidiaries in fact could count on being saved by their parent banks or on funding through their groups. This argument is confirmed by the behavior of the interest rates charged to Italian intermediaries on the overnight unsecured segment of the e-MID market (figure 1) 3 The average rate on overnight loans to Italian banks jumped in the second half of 2011, while that on loans to foreign-owned banks was broadly unchanged; both rates dropped in

\footnotetext{
${ }^{3}$ During the crisis the perception of a substantial stigma effect led borrowers to prefer anonymous to transparent markets; as a consequence, the role of the e-MID in the interbank market decreased significantly. By comparison with the pre-crisis period, the share of very short-term e-MID transactions (overnight, tomorrow next, and spot next) in total transactions (e-MID plus over the counter) dropped from two-thirds to one-third.
} 
Figure 1. Average Overnight Rate in the Unsecured e-MID Market (percentage points)

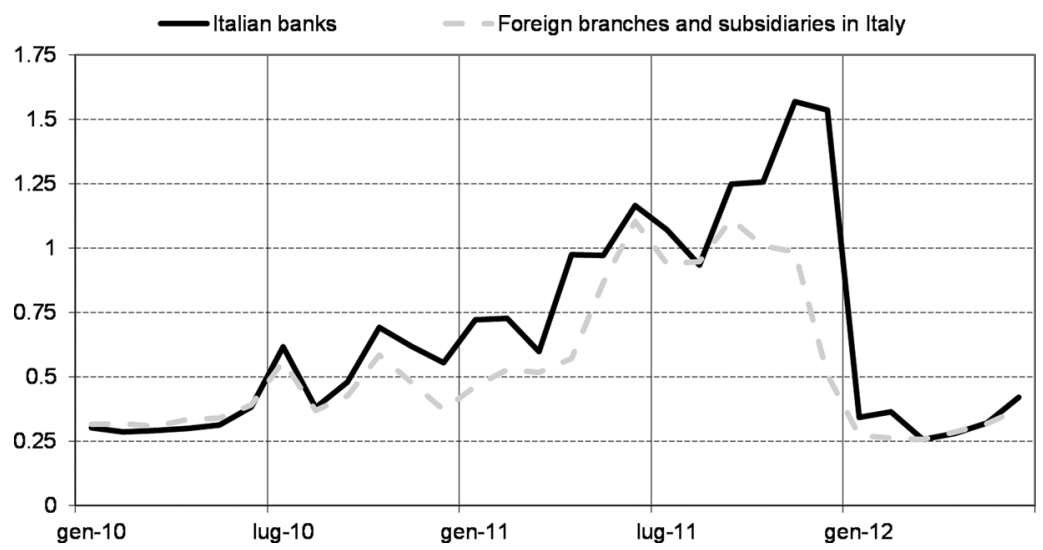

December as a consequence of the ECB's longer-term refinancing operations, which crowded out the market for private funds.

The fact that the funding conditions of foreign-owned banks in Italy were only marginally impaired during the sovereign crisis is confirmed by the data on lending to the non-financial sector. Bofondi, Carpinelli, and Sette (2013) show that during the crisis the corporate lending of Italian banks grew by about 3 percentage points less than that of the subsidiaries of foreign banks, while the interest rate charged by Italian banks was 15 to 20 basis points higher 4

Our data cover all the bilateral borrowing positions between Italian banks and foreign banks. We study the effect of the crisis on the probability that a borrowing relationship will still be standing after the outbreak of the crisis. Our baseline model includes a set of lender and borrower characteristics. We find that the rise in counterparty risk due to the sovereign crisis lowered the probability of an Italian bank's obtaining a loan from a foreign bank by an average of 6 percentage points. The effect is less pronounced for safer-i.e., better capitalized-banks and for more stable relationships, suggesting the importance of asymmetric information.

The paper is structured as follows: the next section examines the related literature, section 3 discusses the data set and the main

\footnotetext{
${ }^{4}$ The same results hold in a macro perspective (Albertazzi et al. 2012).
} 
descriptive statistics, section 4 presents the empirical model and the main results, section 5 describes our robustness checks, and section 6 concludes.

\section{Related Literature}

There is a vast literature on contagion across banks, focusing in particular on how the default of one bank is transmitted to others through balance sheet links (interbank loans, cross-holdings of securities, correlation between portfolios) 5 Simulations suggest that in such networks contagion is likely to be rare, even in the absence of government or central bank intervention (Upper 2011) 6 Karas, Schoors, and Lanine (2008) study other channels of contagion. In particular, using data for the Russian interbank market, they show that the crises of 1998 and 2004 can be replicated by simulations that hypothesize the possibility of liquidity runs. In their model, contagion results from banks calling in loans from the borrowers that suffer substantial losses resulting from the initial default. Their simulations suggest that liquidity runs are one of the main sources of systemic risk in the interbank market and may stem from heightened risk aversion on the part of lenders, increased borrower (counterparty) risk, or both. The practical relevance of these factors in the real world - that is, to what extent the increased counterparty risk could lessen the probability of lending in the interbank market and cause a liquidity run-remains an open question.

One of the causes of the market collapse in 2008 was liquidity hoarding by banks, which ceased to lend out of precaution, given the illiquidity of their assets (Allen, Carletti, and Gale 2009 and Rochet and Tirole 1996). A second channel of contagion was the rise in actual and perceived counterparty risk. In a well-functioning market, counterparty risk induces an increase in the risk premium demanded by the lenders and an adjustment of the amount borrowed, but it does not cause the whole market or part of it to break down. Heider, Hoerova, and Holthausen (2009) propose a theoretical model of the possibility of a failure of the interbank market

\footnotetext{
${ }^{5}$ See, among others, Manna and Schiavone (2012) and Mistrulli (2011).

${ }^{6}$ Affinito (2013) analyzes the effect of the crisis on central bank refinancing, interbank lending, and their interaction.
} 
in the presence of asymmetric information and counterparty risk, hypothesizing that the severity of the crisis depends on the level and distribution of the counterparty risk. When risk is not widely dispersed, the unsecured market works smoothly despite asymmetric information. When risk increases, adverse selection may force safer banks to withdraw from the market and turn to other sources of funding, such as the secured market. However, when both the level and the dispersion of the credit risk are high, the entire market may break down. In this worst-case scenario, banks may be unwilling to lend because of extreme adverse selection or unwilling to borrow because of very high interest rates.

Afonso, Kovner, and Schoar (2011) examine the impact of the financial crisis on the U.S. interbank market. They find that in the days following the Lehman Brothers default, the specific characteristics of borrowing banks became a more important factor in lending banks' decisions, causing increased differentiation on the federal funds market between high-type and low-type borrowers, both in amounts lent and in cost of funds; subsequently, when the government intervened to support systemically important banks, the market returned to pre-crisis levels. Cassola, Holthausen, and Würtz (2008) observe that the economic and financial crisis of 2007-10 exacerbated the problems of cross-country information asymmetry and caused a decline in cross-border transactions within the euro area, consistent with the theoretical results of Freixas and Holthausen (2005).

Our contribution to this literature is to investigate the counterparty risk channel, i.e., the importance of counterparty risk for the interbank market. Where most previous studies concern the post-Lehman crisis, our paper focuses on the effects of the European sovereign debt crisis. Our work is also related to the strand of the literature on the determinants of interbank lending relationships. Affinito (2012), for one, finds that in the Italian market there exist some close, stable relationships between borrowing and lending banks, and that these long-term relationships persisted even during the subprime crisis 7 The persistence of close interbank relations may reflect less severe problems of asymmetric information, hence

${ }^{7}$ Furfine (2001) studies the effects of interbank customer relationships on interbank interest rates in the United States. Cocco, Gomes, and Martins (2009) 
lower counterparty risk. We contribute to this literature by testing whether the counterparty risk channel (that is, the probability that a lending relationship will break up when counterparty risk rises) is related to the characteristics of the lending relationship.

\section{The Italian Interbank Market}

The interbank money market is composed of financial instruments whereby banks exchange short-term funds. The main instruments used by Italian banks are deposits and repurchase agreements. Transactions may take place either on regulated or over-the-counter (OTC) markets 8 The main regulated markets in Italy are e-MID (for unsecured interbank deposits) and MTS (where banks exchange repos). Transactions are bilateral in the OTC and e-MID markets and go through a central counterparty in MTS (and a number of other regulated markets). At the end of 2010, deposits represented more than 80 percent of total interbank positions, of which a third were overnight; repos accounted for slightly less than 20 percent. Including only loans to banks not belonging to the same banking group, the share of overnight loans rises to above 90 percent of the total.

Most transactions take place between banks that belong to the same group (figures 2 and 3). At the end of 2010, total interbank balance sheet liabilities of Italian banks amounted to $€ 760$ billion. Intra-group assets made up over 70 percent of total interbank exposures (65 percent before the crisis). The top five groups accounted for about 65 percent of all positions, and this share increased during the crisis. In the pre-crisis period the importance of foreign counterparties increased considerably. At the end of 2010, liabilities vis-à-vis foreign banks accounted for more than 50 percent of total extragroup balance sheet positions (most of these within the top five groups).

In this paper we seek to measure the extent to which the increase in counterparty risk curtailed Italian banks' access to foreign bank

include some of the determinants of interbank customer relationships in their analysis.

${ }^{8}$ See Affinito (2013) and Cappelletti et al. (2011) for an account of developments in the Italian interbank market in the first part of the crisis. 


\section{Figure 2. The Italian Unsecured Interbank Market (€billions)}

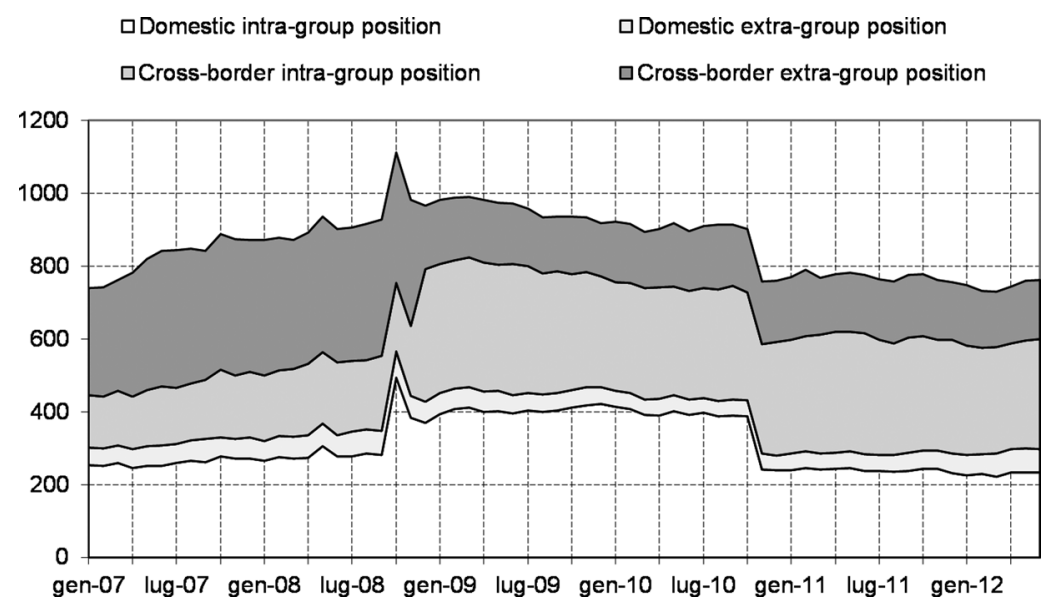

lending. Transactions that involve banks not belonging to the same banking group or banks domiciled in different countries are naturally more information sensitive, and all the more so where they are not backed by collateral or guaranteed by a central counterparty 9 Therefore, we focus on extra-group and unsecured loans as transactions that involve banks domiciled outside Italy and Italian banks 10 Our analysis focuses accordingly on the unsecured segment of the market and on foreign lenders, which we assume have less precise credit information on Italian borrowers than domestic banks and are more sensitive to changes in credit risk. Moreover, focusing on foreign lenders helps us to distinguish counterparty risk from the liquidity hoarding channel, since some foreign banks were less severely affected by the crisis and so had little incentive for precautionary hoarding.

\footnotetext{
${ }^{9}$ The financial turmoil severely affected the extra-group, foreign, and unsecured segments of the market, which are characterized by higher counterparty risk and higher information sensitivity. Following the outbreak of the crisis, the market shifted from bilateral to central counterparty transactions and from long-term to short-term instruments.

${ }^{10}$ Excluding intra-group loans is standard practice in studies on interbank loans, as intra-group loans may also respond to group-specific motivations, such as liquidity reallocations among group subsidiaries.
} 
Figure 3. Cross-Border Position by Bank Residence (€billions; base: June $2011=100$ )
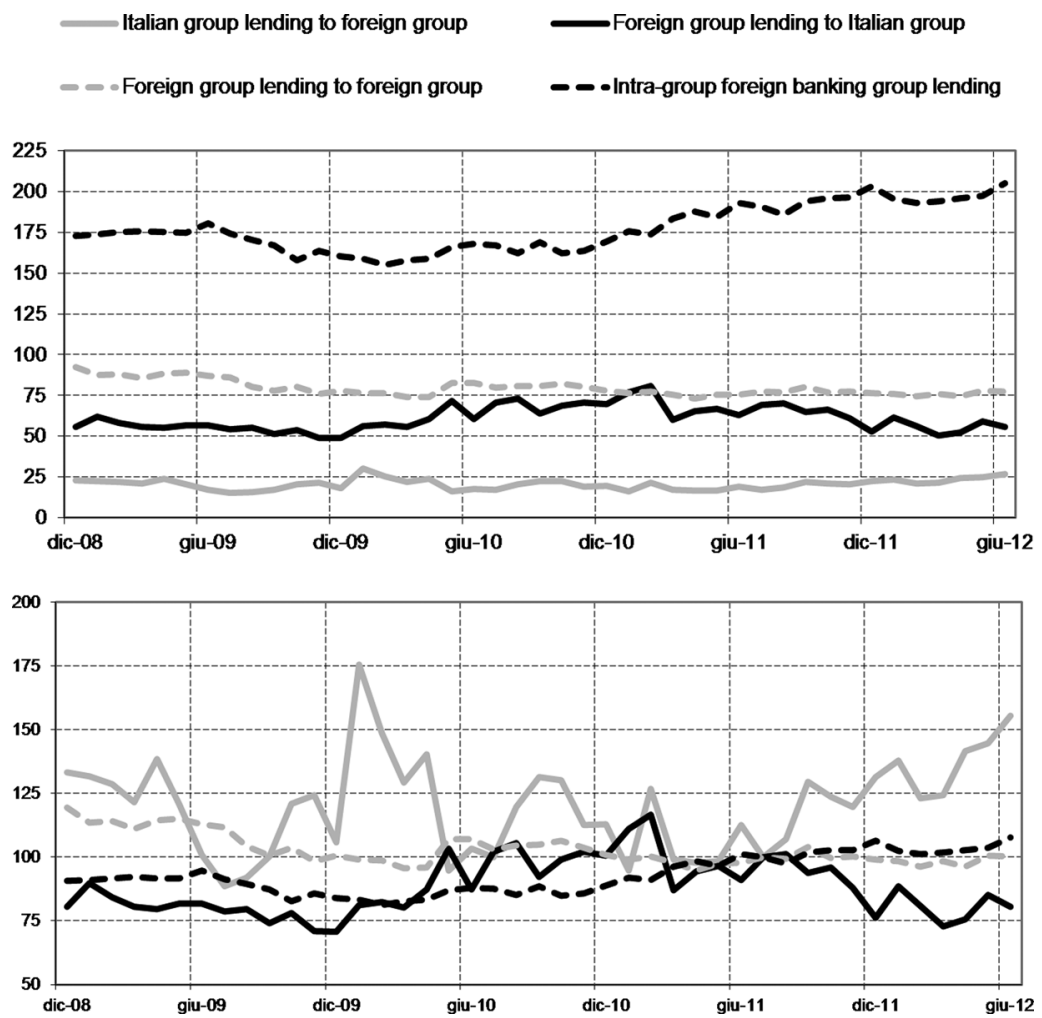

We use monthly balance sheet information on the interbank borrowing positions of Italian banks from January to December 2011. The data come from the Bank of Italy's prudential supervisory reports, which give the gross bilateral exposures (assets and liabilities) of each Italian bank with respect to all other banks, both domestic and foreign. With these data we can distinguish between intragroup and extra-group and between secured and unsecured positions. Still, we do not observe the balance sheet characteristics of foreign lenders, apart from their exposure to the Italian market. Information on single transactions can be retrieved either through TARGET or e-MID, but neither of these sources guarantees a complete picture 


\section{Table 1. Italian Banks' Unsecured Foreign Borrowing Positions}

\begin{tabular}{|c|c|c|c|c|c|c|}
\hline & $\begin{array}{l}\text { Dec. } \\
2006\end{array}$ & $\begin{array}{l}\text { Dec. } \\
2009\end{array}$ & $\begin{array}{l}\text { Jun. } \\
2010\end{array}$ & $\begin{array}{l}\text { Dec. } \\
2010\end{array}$ & $\begin{array}{l}\text { Jun. } \\
2011\end{array}$ & $\begin{array}{l}\text { Dec. } \\
2011\end{array}$ \\
\hline $\begin{array}{l}\text { Total Interbank Secured Loans } \\
\text { (Extra-group) (1) }\end{array}$ & 40 & 38 & 54 & 60 & 77 & 73 \\
\hline $\begin{array}{l}\text { Total Interbank Loans Through } \\
\text { Central Counterparties (1) }\end{array}$ & 21 & 44 & 101 & 117 & 107 & 72 \\
\hline Total Interbank Unsecured Loans (1) & 959 & 914 & 959 & 744 & 766 & 746 \\
\hline Of which: Intra-group & 529 & 447 & 529 & 463 & 482 & 459 \\
\hline Of which: Cross-Border & 615 & 621 & 615 & 455 & 459 & 422 \\
\hline $\begin{array}{l}\text { Of which: Intra-group } \\
\text { Cross-Border }\end{array}$ & 240 & 198 & 240 & 214 & 220 & 187 \\
\hline $\begin{array}{l}\text { Number of Banks (Borrowing from } \\
\text { Foreign Banks in } 2010 \text { or in 2011) }\end{array}$ & 224 & 221 & 220 & 211 & 210 & 209 \\
\hline Italian Banks & 148 & 152 & 152 & 143 & 141 & 137 \\
\hline $\begin{array}{l}\text { Foreign Branches and } \\
\text { Subsidiaries }\end{array}$ & 76 & 69 & 68 & 68 & 69 & 72 \\
\hline $\begin{array}{l}\text { Average Number of Unsecured } \\
\text { Borrowing Position }\end{array}$ & 13 & 13 & 13 & 12 & 12 & 11 \\
\hline Italian Banks & 11 & 14 & 14 & 13 & 13 & 12 \\
\hline $\begin{array}{l}\text { Foreign Branches and } \\
\text { Subsidiaries }\end{array}$ & 19 & 11 & 11 & 10 & 9 & 9 \\
\hline $\begin{array}{l}\text { Total Value Borrowing Position } \\
\text { (Billions) }\end{array}$ & 213 & 177 & 184 & 179 & 188 & 183 \\
\hline Italian Banks & 54 & 55 & 66 & 61 & 65 & 53 \\
\hline $\begin{array}{l}\text { Foreign Branches and } \\
\text { Subsidiaries }\end{array}$ & 158 & 122 & 118 & 118 & 123 & 130 \\
\hline
\end{tabular}

of banks' borrowing capacity, so we rely only on supervisory data regarding overall banks' borrowing positions.

The sample consists of 269 banks, of which more than 60 were branches or subsidiaries of foreign banks and the rest were members of Italian groups or solo banks (table 1). In order to identify the effect of the increase in the riskiness of Italian banks, we focused on unsecured loans, because this is the largest component of banks' funding and because in collateralized transactions (either secured or through central counterparty) the borrower's creditworthiness 


\section{Table 2. Branches or Subsidiaries of Foreign Banks Operating in Italy (€millions, units; at the end of 2011)}

\begin{tabular}{|l|c|c|}
\hline Country & $\begin{array}{c}\text { Number of } \\
\text { Banks (1) }\end{array}$ & $\begin{array}{c}\text { Outstanding } \\
\text { Interbank Deposit(2) }\end{array}$ \\
\hline United Kingdom & 10 & 38,497 \\
France & 15 & 23,855 \\
Germany & 12 & 22,386 \\
Spain & 7 & 12,291 \\
The Netherlands & 6 & 6,825 \\
United States of America & 3 & 2,978 \\
Ireland & 2 & 2,943 \\
Japan & 2 & 2,659 \\
Luxembourg & 5 & 567 \\
Switzerland & 1 & 304 \\
\hline
\end{tabular}

Notes: (1) Number of branches or subsidiaries of foreign banks operating in Italy. (2) Interbank unsecured loans from foreign banks. Reference date: December 31, 2011.

matters less. Foreign banks having branches or subsidiaries operating in Italy are mainly domiciled in European countries. The most relevant are domiciled in the United Kingdom, France, Germany, and Spain (table 2).

We study the effect of the increase in credit risk, positing that the euro-area sovereign debt crisis was exogenous with respect to the riskiness of individual banks. In the second half of 2011, the spread between Italian and German government bonds soared from 190 basis points at the end of June to over 400 basis points at the end of December. In the same period, unsecured transactions, especially lending from foreign counterparties, decreased substantially. At the end of 2010, unsecured foreign loans had amounted to $€ 120$ billion, of which $€ 50$ billion were to Italian banks and $€ 70$ billion were to foreign-owned banks. The overall value oscillated around that amount in the first half of 2011 but declined sharply, by almost 10 percent, in the second half.

The patterns of lending to Italian and to foreign-owned banks diverged significantly in the course of the crisis: while foreign loans to banks belonging to foreign groups remained almost unchanged, those to Italian groups shrank by 16 percent. More than four-fifths of 
the decline reflected the discontinuance of lending relationships, and the rest a reduction in the value of outstanding loans. Meanwhile, the distribution of borrowing positions across lenders became more concentrated. As a consequence of reduced foreign funding, Italian banks increased their financing from the Eurosystem. The resources raised served not only to offset the contraction in foreign lending but also to hoard liquidity against the refinancing risk of maturing bonds.

Italian banks' capacity to obtain funds through their foreign branches diminished even more sharply 11 In November 2011 there was also a steep fall in transactions through central counterparties, presumably in connection with the loss of value of Italian government bonds as collateral 12

\section{The Model and the Results}

We exploit the sovereign debt crisis to measure the effect of an exogenous increase in the credit risk of Italian banking groups in the interbank market. Our identification strategy relies on differencein-differences methodology. The outbreak of the crisis in Italy was basically exogenous with respect to the lending policies of Italian banks. Both low growth and high public debt are long-standing features of the Italian economy. Nor was the Italian banking system a source of instability for the public finances (see, among others, International Monetary Fund 2010 Article IV consultation on Italy) and Italy did not experience any housing bubble. In short, the skyrocketing of Italian sovereign spreads starting in July 2011 was not triggered by any specific domestic event (Bofondi, Carpinelli, and Sette 2013).

\footnotetext{
${ }^{11}$ Such transactions are not considered in the analysis, insofar as they are loans to foreign banks.

${ }^{12}$ In the previous years, during the subprime crisis, foreign lending to Italian banks shifted in part from bilateral to central counterparty transactions, to reduce counterparty risk. Foreign lending through central counterparties declined again with the outbreak of the sovereign crisis, presumably due to the decline in the value of Italian government bonds used as collateral. In this paper, however, we only consider bilateral positions, for which we know the identity of both parties.
} 
Therefore, we can adopt a quasi-experimental methodology 13 exploiting the sharp increase in the yield on Italian sovereign debt in July 2011. The period studied runs from January to December 2011: the pre-treatment period is from January to June and the posttreatment period is from July to December, when interest rates on Italian government bonds increased. The treatment group consists of Italian group or independent banks, the control group of foreignowned banks operating in Italy. The observations are the borrowing positions of each sample bank with respect to each foreign bank at the end of each month.

We first estimate a standard linear model for the percentage change in unsecured loans. The results confirm that banks belonging to Italian groups suffered a sharper reduction than foreign-owned banks in lending from foreign banks (table 3). Given the volatility of the dependent variable and the relatively short time span, when we tried to factor in bank fixed effects the significance of the estimates diminished significantly.

Accordingly, we elected to focus on the probability of foreign bank $f$ lending to an Italian bank $i$ at time $t$ using the following logit model 14

$$
\begin{gathered}
\operatorname{Pr}\left(L_{i, f, t}>0 \mid X\right) \\
=\operatorname{Logit}_{\left(\alpha+\text { Post }_{t}+\gamma \text { Treat }_{i}+\text { STreat }_{i} * \text { Post }_{t}+\eta X_{i, t}+\varphi Y_{f, t}\right),}^{(1)}
\end{gathered}
$$

where $L_{i, f, t}$ is the gross position between borrower $i$ and lender $f$ at time $t$; Treat $_{i}$ is a dummy variable equal to 1 if $i$ belongs to an Italian banking group and equal to 0 if it is a branch or subsidiary of a foreign bank; Post $t_{t}$ is equal to 1 if time $t$ is equal to December 2011 (i.e., after the tensions in the government bond market increased sharply) and equal to 0 if time $t$ is equal to June 2011. $X_{i, t}$ is a set of controls specific for each borrower $i$ and time $t$. $Y_{f, t}$ is a set of controls specific for each lender $f$ and time $t$. We control for borrower $i$ overall interbank positions (distinguishing between secured and unsecured transactions) and borrower $i$ balance sheet characteristics. In particular, based on borrowers' balance sheet data we can control for

\footnotetext{
${ }^{13}$ See Imbens and Wooldridge (2009).

${ }^{14}$ We tried a variety of statistical models, linear probability models, and probit and tobit models, always obtaining the same results.
} 


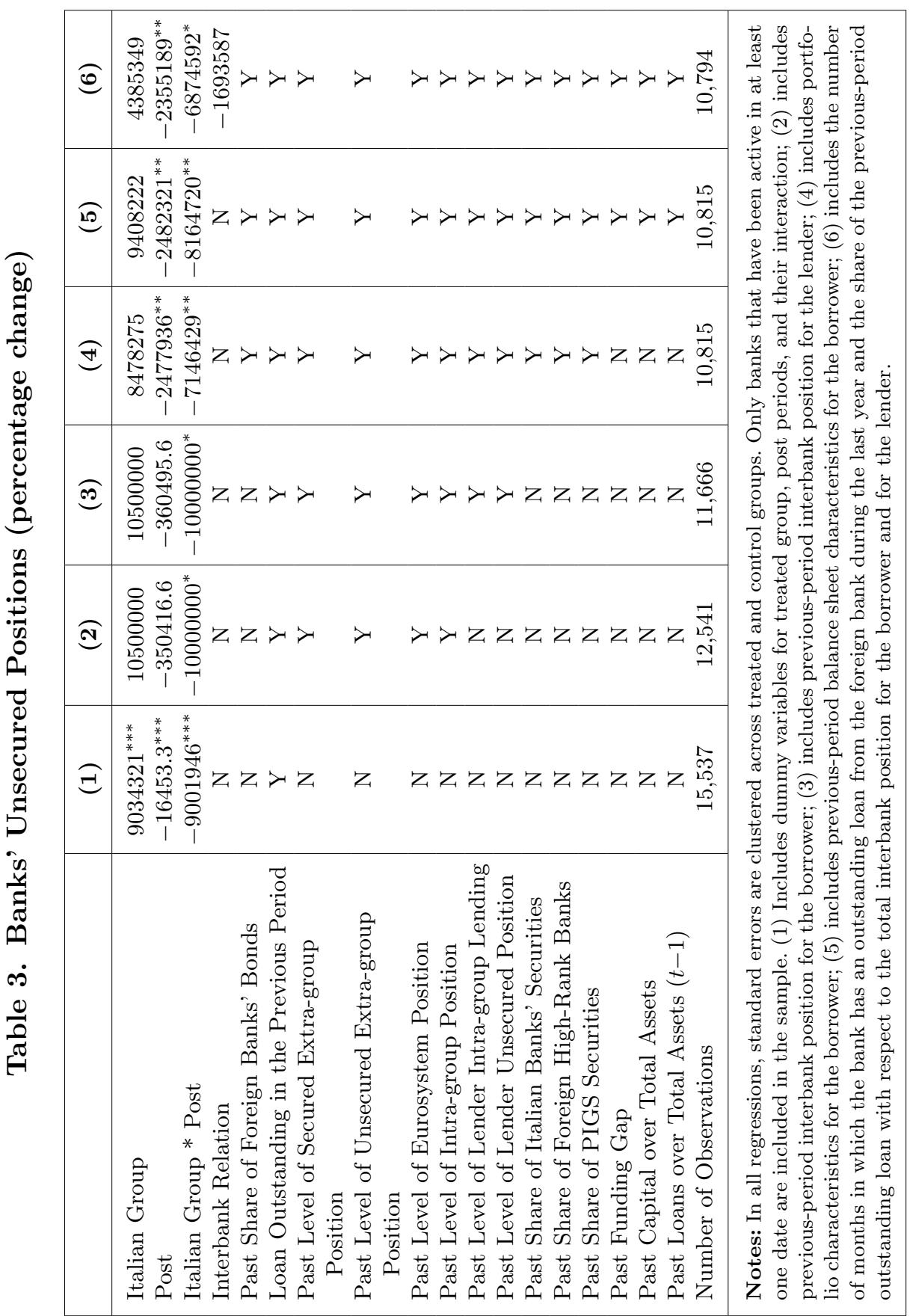


outstanding capital, funding capacity, lending activity, asset composition (i.e., the share of securities issued by firms domiciled in countries with lower ratings, the share of high-rated euro-area banking groups), and outstanding bad loans. Since we focus on foreign lenders, we could include among the controls only lender $f$ 's overall interbank position vis-à-vis Italian banks.

Table 4 shows our baseline estimate. The effect of the rise in counterparty risk on the probability of an Italian bank receiving a loan from a foreign bank is negative, and the coefficient is statistically significant. The descriptive evidence - namely, that foreign banks cut their lending to Italian banks more sharply than that to foreign bank branches and subsidiaries - is therefore confirmed in our multivariate framework, where we control for observable bank characteristics. While the coefficient of the interaction term gives us the sign of the effect, to estimate its magnitude we need to compute the average treatment effect on the treated, which is equal to

$$
\begin{gathered}
\left.\tau \text { Post }_{i}=1, \text { Treat }_{t}=1, X_{i, t}, Y_{f, t}\right) \\
:=\frac{\Delta^{2} E\left(Y_{i, f, t} \mid \text { Treat }_{i}=1, \text { Post }_{t}=1, X_{i, t}, Y_{f, t}\right)}{\Delta \text { Treat } \text { Post }} \\
\quad-\frac{\Delta^{2} E\left(Y_{i, f, t}^{0} \mid \text { Treat }_{i}=1, \text { Post }_{t}=1, X_{i, t}, Y_{f, t}\right)}{\Delta \text { Treat }_{\text {Post }}},
\end{gathered}
$$

where $Y_{i, f, t}^{0}$ is the counterfactual outcome for the treated bank had it not been treated (Puhani 2012). The associated standard errors are computed using delta methods. Given the usual identification assumptions, the average treatment effect is equal to

$$
\begin{gathered}
\left.\tau \text { Post }_{i}=1, \text { Treat }_{t}=1, X_{i, t}, Y_{f, t}\right) \\
=\operatorname{Logit}\left(\alpha+\beta+\gamma+\delta+\eta X_{i, t}+\varphi Y_{f, t}\right) \\
\quad-\operatorname{Logit}\left(\alpha+\beta+\gamma+\eta X_{i, t}+\varphi Y_{f, t}\right) .
\end{gathered}
$$

These estimates show that in the wake of the sovereign crisis the probability of an Italian bank obtaining a loan from a foreign bank decreased by about 6 percentage points in comparison with branches or subsidiaries of foreign groups (table 4). Moreover, the effect varies within the set of banks hit by the shock, with a maximum effect of 


\begin{tabular}{|c|c|c|c|c|}
\hline eै & 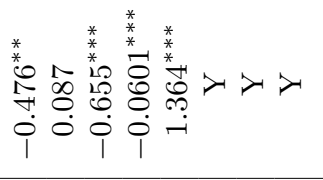 & $\succ$ & $\lambda \succ \lambda \succ \lambda \succ \lambda \succ \lambda \succ \underset{0}{\stackrel{0}{0}}$ & 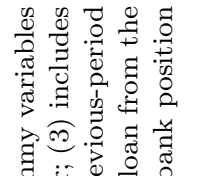 \\
\hline$\sqrt{10}$ & 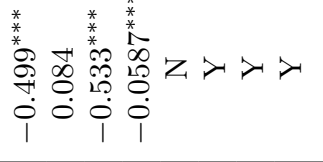 & $\lambda$ & 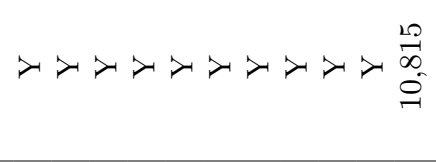 & 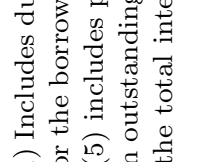 \\
\hline$\nexists$ & 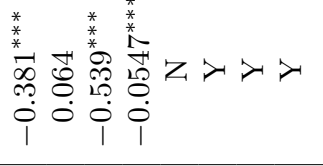 & $\lambda$ & 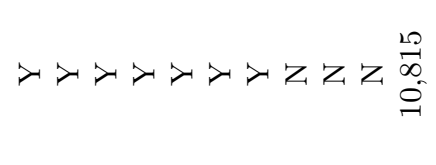 & 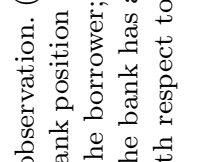 \\
\hline (9) & 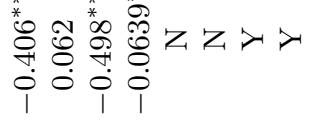 & $\lambda$ & 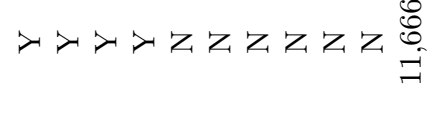 & 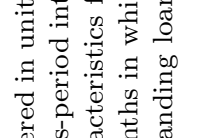 \\
\hline$\widehat{\mathfrak{c}}$ & 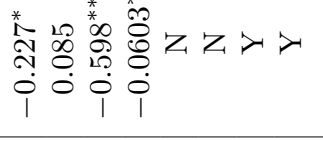 & $\lambda$ & 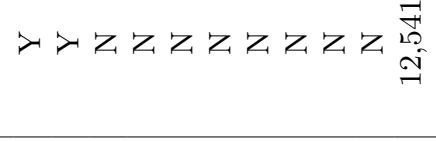 & 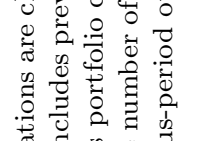 \\
\hline$\Xi$ & 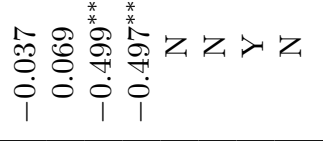 & Z & 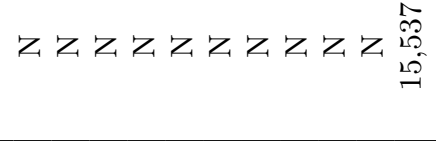 & 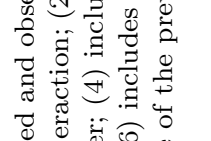 \\
\hline & 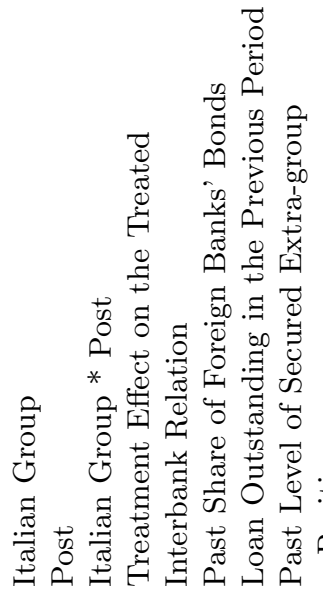 & 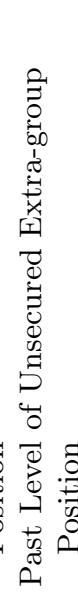 & 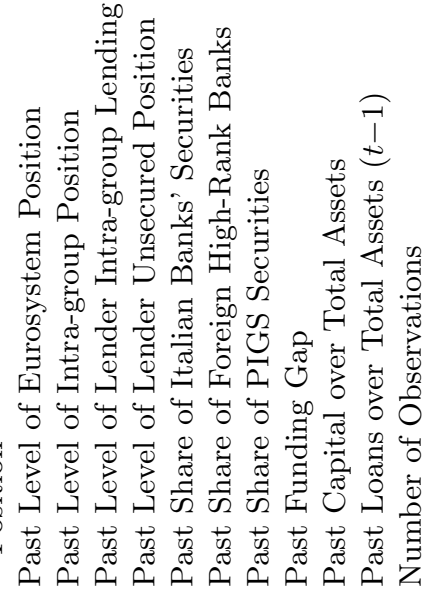 & 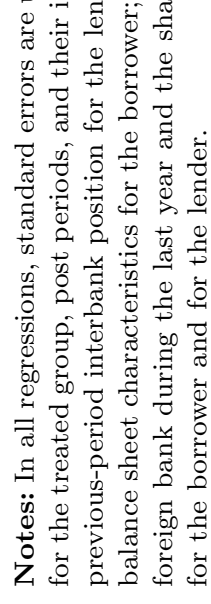 \\
\hline
\end{tabular}




\section{Figure 4. Distribution of the Average Treatment Effect on the Treated}

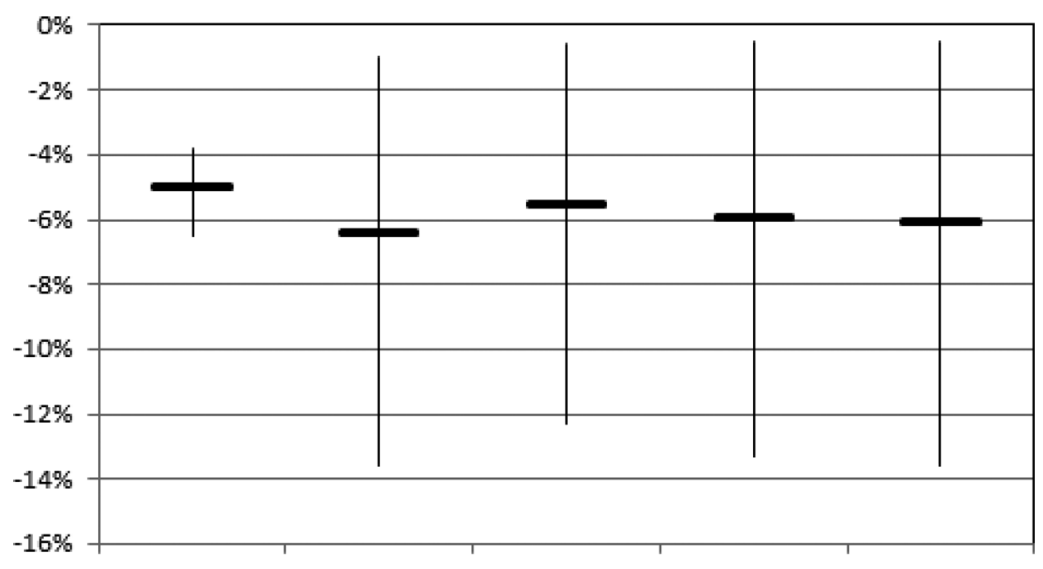

(1)

(2)

(3)

(4)

(5)

Model specification:

(1) Includes dummy variables for treated group, post periods, and their interaction;

(2) Includes previous-period interbank position for the borrower;

(3) Includes previous-period interbank position for the lender;

(5) Includes portfolio characteristics for the borrower;

(6) Includes previous-period balancesheet characteristics for the borrower.

more than 10 points (figure 4). Including only subsidiaries of foreign banking groups, the estimate does not change (table 5).

The European sovereign debt crisis affected a good many countries, including Croatia, Cyprus, Greece, Ireland, Malta, Spain, Portugal, and Slovenia. Banks domiciled in these non-core countries could have had an incentive to hoard liquidity and cut lending to all other banks, regardless of their creditworthiness. To disentangle the counterparty risk and the liquidity hoarding motives, we estimate equation (1) separately for foreign lenders domiciled in core countries (Austria, Belgium, Finland, France, Germany, and Luxembourg) and non-core countries (Croatia, Cyprus, Greece, Ireland, Malta, Spain, Portugal, and Slovenia). The hypothesis is that banks domiciled in non-core countries should have reduced their lending to all banks in Italy, whether Italian owned (treated group) or foreign owned (control group), since these lenders themselves were damaged 


\begin{tabular}{|c|c|c|c|c|}
\hline (e) & 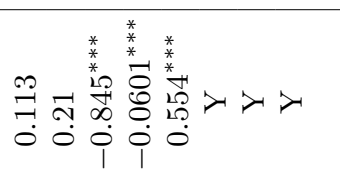 & $>$ & 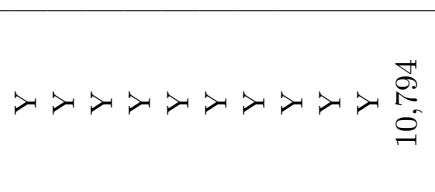 & 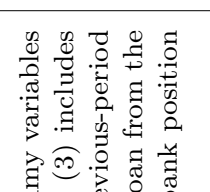 \\
\hline$\sqrt{6}$ & 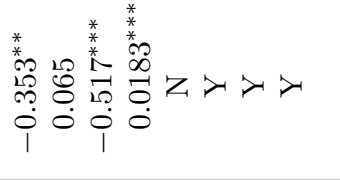 & $\lambda$ & 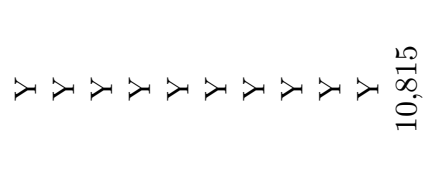 & 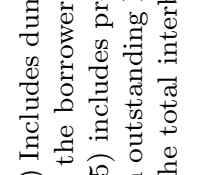 \\
\hline (્t & 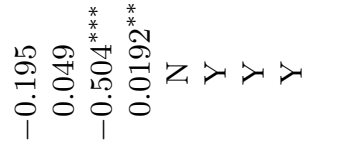 & $\succ$ & 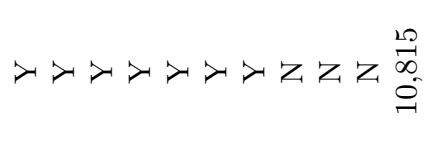 & 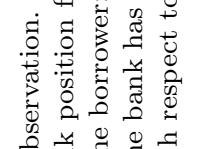 \\
\hline$\widehat{\vartheta}$ & 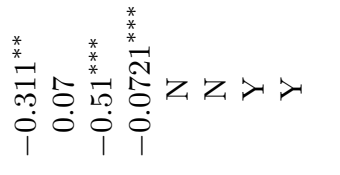 & $>$ & 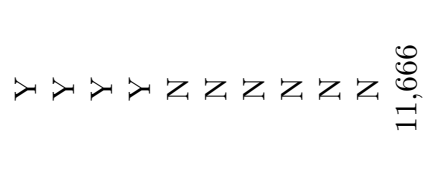 & 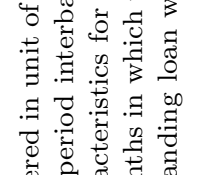 \\
\hline$\widehat{(1)}$ & 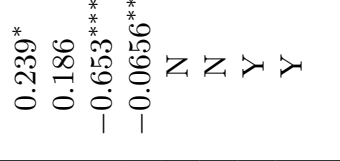 & $\succ$ & 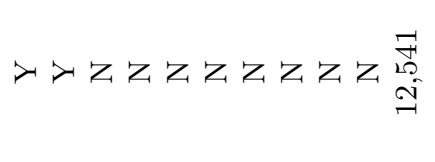 & 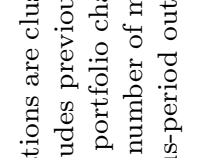 \\
\hline$\Xi$ & 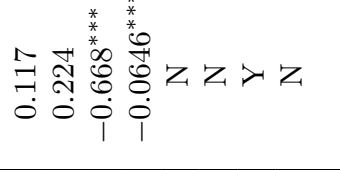 & z & 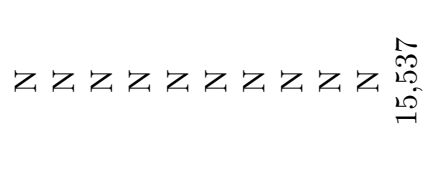 & 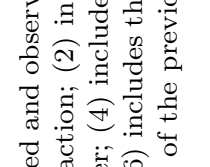 \\
\hline & 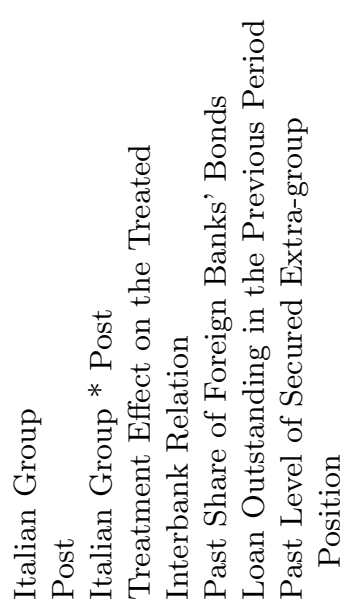 & 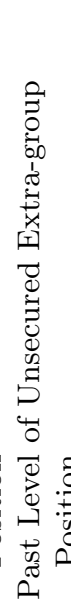 & 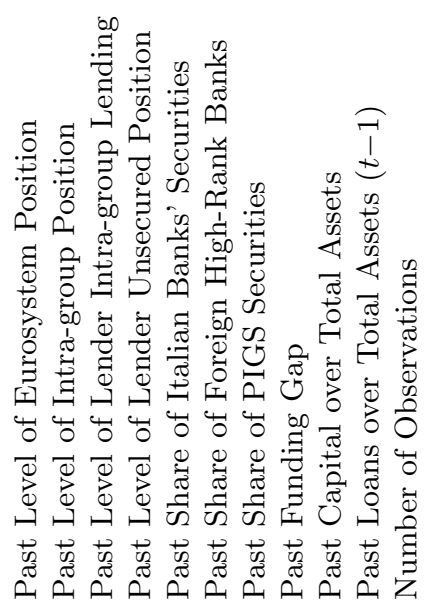 & 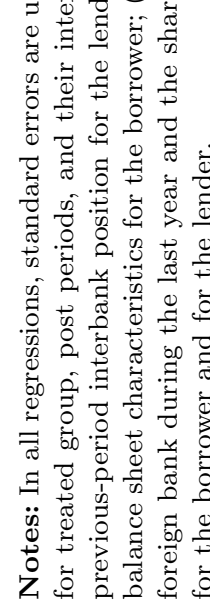 \\
\hline
\end{tabular}


by the sovereign crisis and stopped lending for precautionary motives (liquidity hoarding). And, in fact, in this estimation the probability of Italian banks' receiving funding from foreign banks domiciled in core countries falls by around 10 percentage points against 6 percentage points in the baseline estimation (table 6 , columns 3 and 4), while the estimated change in lending from foreign banks domiciled in non-core countries is not statistically different from zero (table 6 , columns 1 and 2). As a further robustness check, we estimate the baseline model with a control group consisting only of Italian banks that are either branches or subsidiaries of groups domiciled in noncore euro-area countries. The differential effect is now statistically non-significant (table 6, columns 5 and 6), which further suggests that we are in fact capturing the effect of the increased counterparty risk provoked by the sovereign debt crisis 15

In order to check whether foreign lenders behaved differently according to the borrower's financial soundness, we run an estimate with a treated group consisting only of Italian banks in the top quartile of ratios of capital to total assets. The last two columns of table 6 show that for these banks the probability of receiving funds from abroad did not decrease more than that for branches and subsidiaries of foreign groups. This suggests that the crisis did not affect lenders' ability to assess borrowers' creditworthiness.

We also seek to determine the factors that amplified or attenuated the reduction of funding from foreign banks as a result of the increase in counterparty risk. First we test whether the betterinformed banks, i.e., groups with branches or subsidiaries in Italy, were less affected by the heightened credit risk of Italian banks, in that this diminished effect might reflect the fact that these banks have more information on the creditworthiness of Italian banks. However, we find that having a branch or a subsidiary in Italy has no statistically significant effect on the probability of lending to an Italian bank. Possibly foreign banks with affiliates in Italy replaced extra-group with intra-group lending 16

\footnotetext{
${ }^{15}$ The sovereign debt crisis also affected the composition by duration of interbank loans. Loans between banks not belonging to the same banking group were almost entirely overnight.

${ }^{16}$ If the total exposure to a given country is limited, the foreign parent company decides whether to grant a loan to a group member or to a non-group bank.
} 


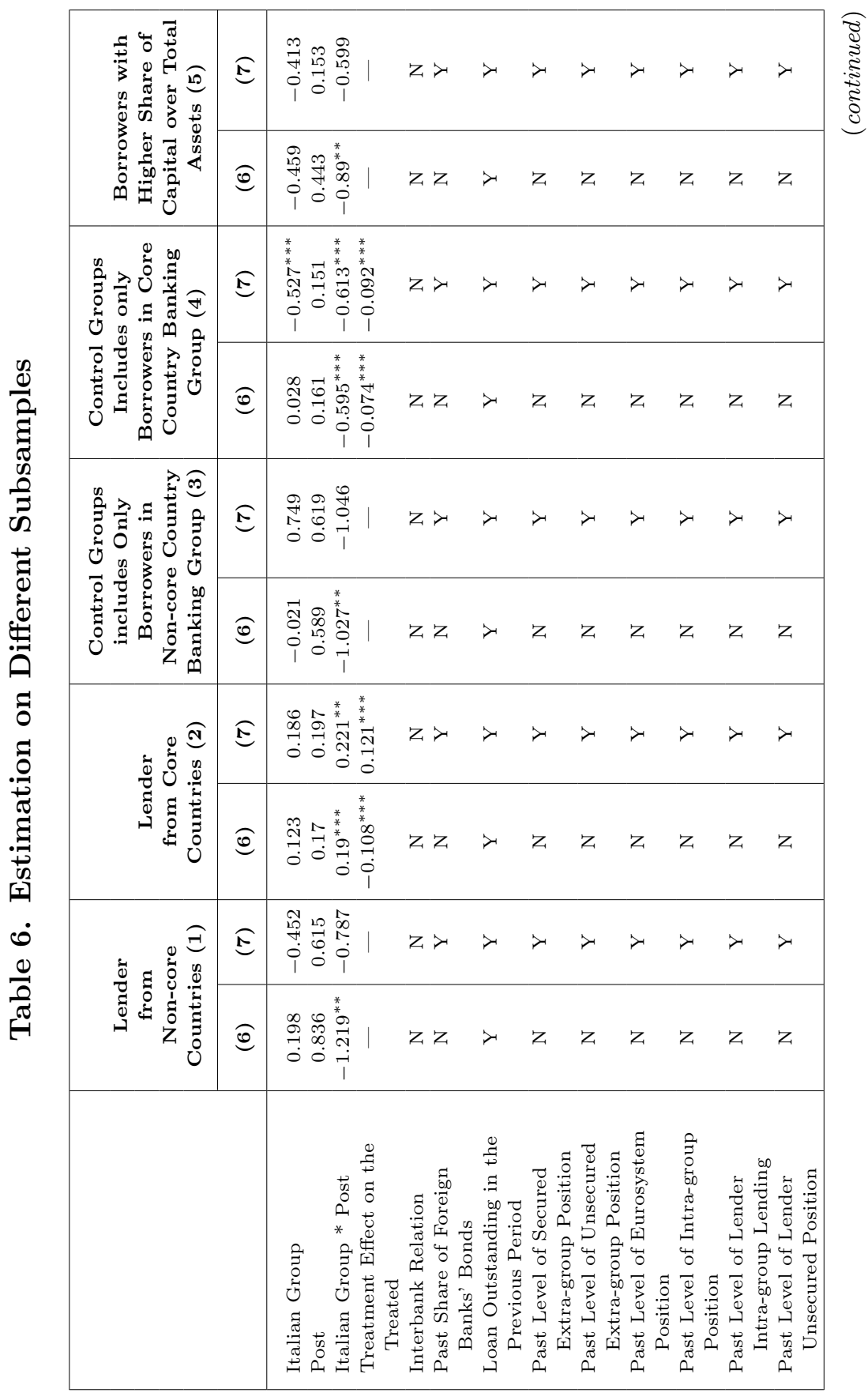




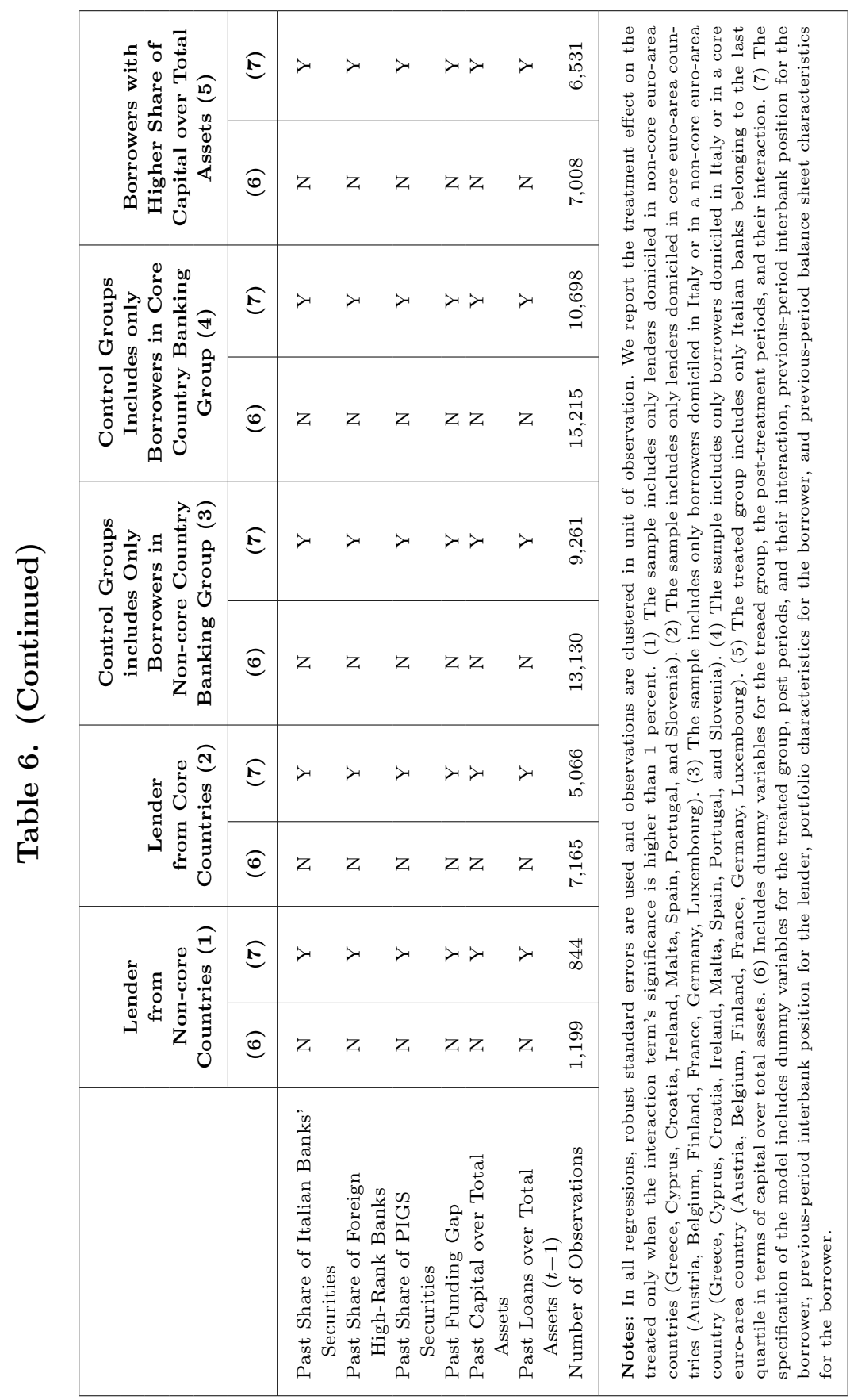


Next we test whether the effect of the increase in counterparty risk is influenced by the existence of a lending relationship, either because lenders discount the long-term value of the relationship or because lending relationships reduce information asymmetry. To test this hypothesis we need to jettison the assumption of constant treatment effect and instead consider different subsamples according to the number of months in which a lending position was in being 17 We find that long-term relationships were in fact more resilient to the crisis (table 7 ). These results are in line with the findings of Affinito (2012) on the importance of interbank customer relations for Italian banks.

\section{Robustness Checks}

In principle, domestic and foreign banks may differ in several dimensions, so that it may not be warranted to compare them in order to gauge how the increase in sovereign spreads affected the probability of receiving funds from abroad. However, Bofondi, Carpinelli, and Sette (2013) rebut this argument on a number of grounds. First, the Italian banking system is sophisticated and Italian banks, especially the larger ones, have business models, lending technologies, and geographical scope similar to those of foreign subsidiaries. Second, our regressions include bank fixed effects, controlling for all unobserved heterogeneity among lenders, and in particular for differences in the ex ante composition of loan portfolios, lending policies, and the extent of the network of outlets.

As a further robustness check, in order to adjust for differences in observable characteristics, we match each treated bank with a similar control-group bank based on a propensity score (Rosenbaum and Rubin 1983). Table 8 reports summary statistics for the control variables in the first half of 2011, distinguishing between Italian and foreign-owned banks. For each variable, the table also shows the simple difference of the characteristics between the two groups before and after the sample has been matched based on the propensity

\footnotetext{
${ }^{17}$ There are some econometric difficulties in determining whether the treatment has an effect on some subsamples, defined by observable characteristics (see Lee and Shaikh 2013).
} 


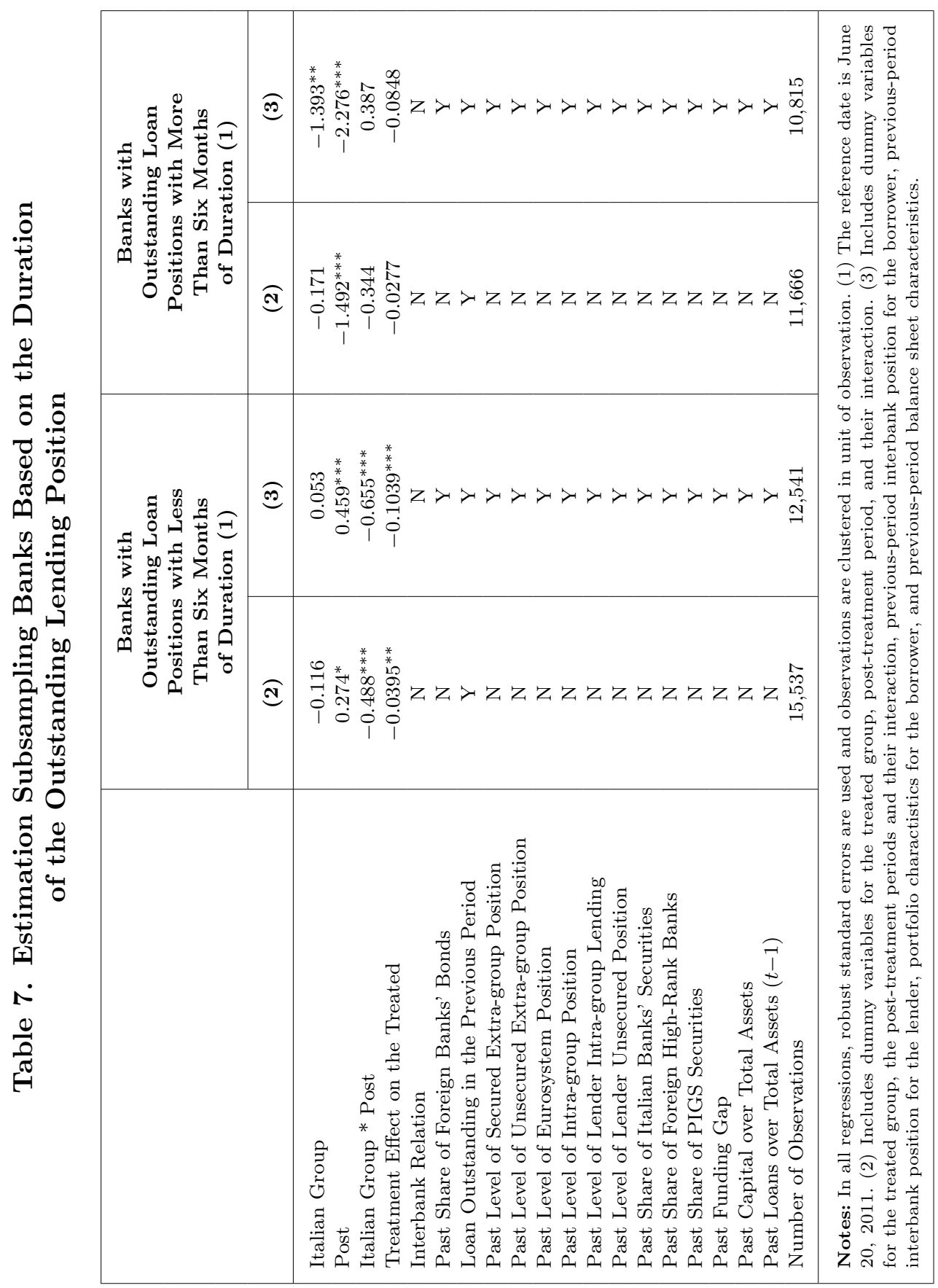




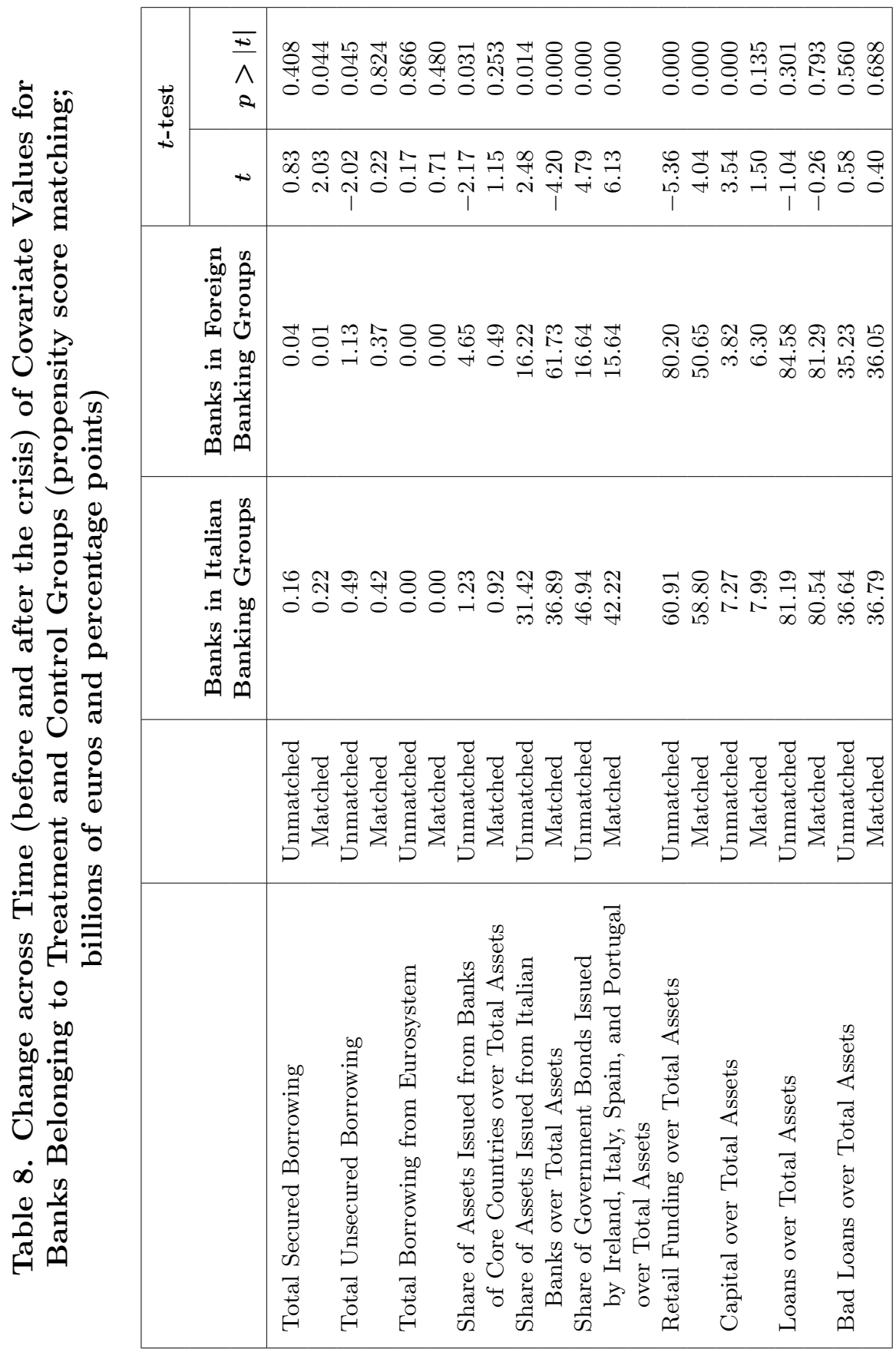


score (Abadie 2005). Note that the Italian banks have proportionally more assets in securities issued by other Italian banks and proportionally less in securities issued by firms domiciled in high-rated countries. The differences in lending activity are not statistically significant. The differences in observable characteristics could indicate that foreign-owned banks may not be a good control group to estimate the outcome for Italian banks on the counterfactual hypothesis of their not being treated. The estimates produced by such simple comparison of outcomes, that is, may be biased.

Consequently, we select a subsample of branches and subsidiaries of foreign banking groups in order to control fully for observable differences between the treated and the control groups. We match banks based on the propensity score $\left(p\left(X_{i, t}\right)\right)$, which measures the conditional probability of a deterioration in creditworthiness given the covariates $X_{i, t}$. First we estimate the propensity score running a logit estimate on observable bank characteristics and then we use nearest-neighbor matching without replacement to pair each Italian bank with the foreign bank closest to it in estimated $p\left(X_{i, t}\right)$. To improve the match, we drop the banks whose propensity score falls outside the support of the propensity score of foreign banks (figure 5) 18 We run both linear probability and non-linear models, considering different sets of controls. Tables 9 and 10 show the estimates, which confirm those of the baseline model, with an increase in the point estimate of the average treatment effect.

Given the non-linear relation between exogenous and dependent variables, interpreting a difference-in-difference (DID) estimate in non-linear models is difficult (Ai and Norton 2003; Lechner 2011; Puhani 2012). To overcome this problem, as a robustness check we perform a change-in-change (CIC) estimate, following Athey and Imbens (2006). This enables us to drop the assumption of linear relation between unobservable characteristics and the probability of a loan. Moreover, the distribution of unobservables may differ between treatment and control group, although we have to assume that this distribution does not depend on whether the bank is in the control or the treatment group.

\footnotetext{
${ }^{18}$ See Abadie and Imbens (2006), Becker and Ichino (2002), Caliendo and Kopeinig (2008), and Leuven and Sianesi (2003).
} 
Figure 5. Common Support between Treated and Control Group

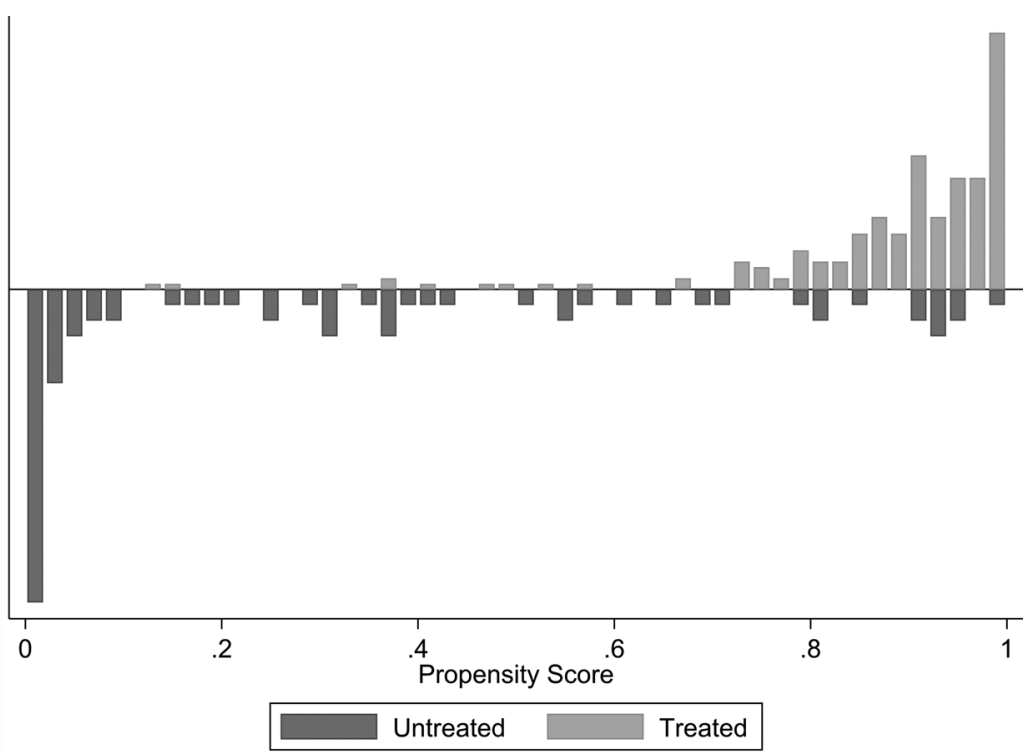

We examine only the bilateral positions at the end of June and July 2011, running an unconditional estimate on the discrete outcome variable that indicates whether or not bank $i$ is lending to bank $f$ at a certain date; in this setting a point estimate is possible only if we assume conditional independence between unobservable characteristics and membership of the treated group; otherwise we can only estimate an upper and a lower bound of the average treatment effect. This estimate shows that the difference between Italian and foreign banks is small but still significant.

We then assume that the probability of getting a loan depends linearly on our explanatory variable and assume a non-linear function of unobserved characteristics of borrower and lenders, of time $(t)$ and of the treatment

$$
1_{\left\{L_{i, f, t}>0\right\}}\left(L_{i, f, t}\right)=\alpha+\eta X_{i, t}+\varphi Y_{f, t}+h^{k}\left(u_{i, f}, t\right),
$$

where $h^{k}$ is a weakly monotonic function of unobservable characteristics $u_{i, f}$ and of time, and it is indexed on being treated or not $(k \in\{N I, I\})$. 


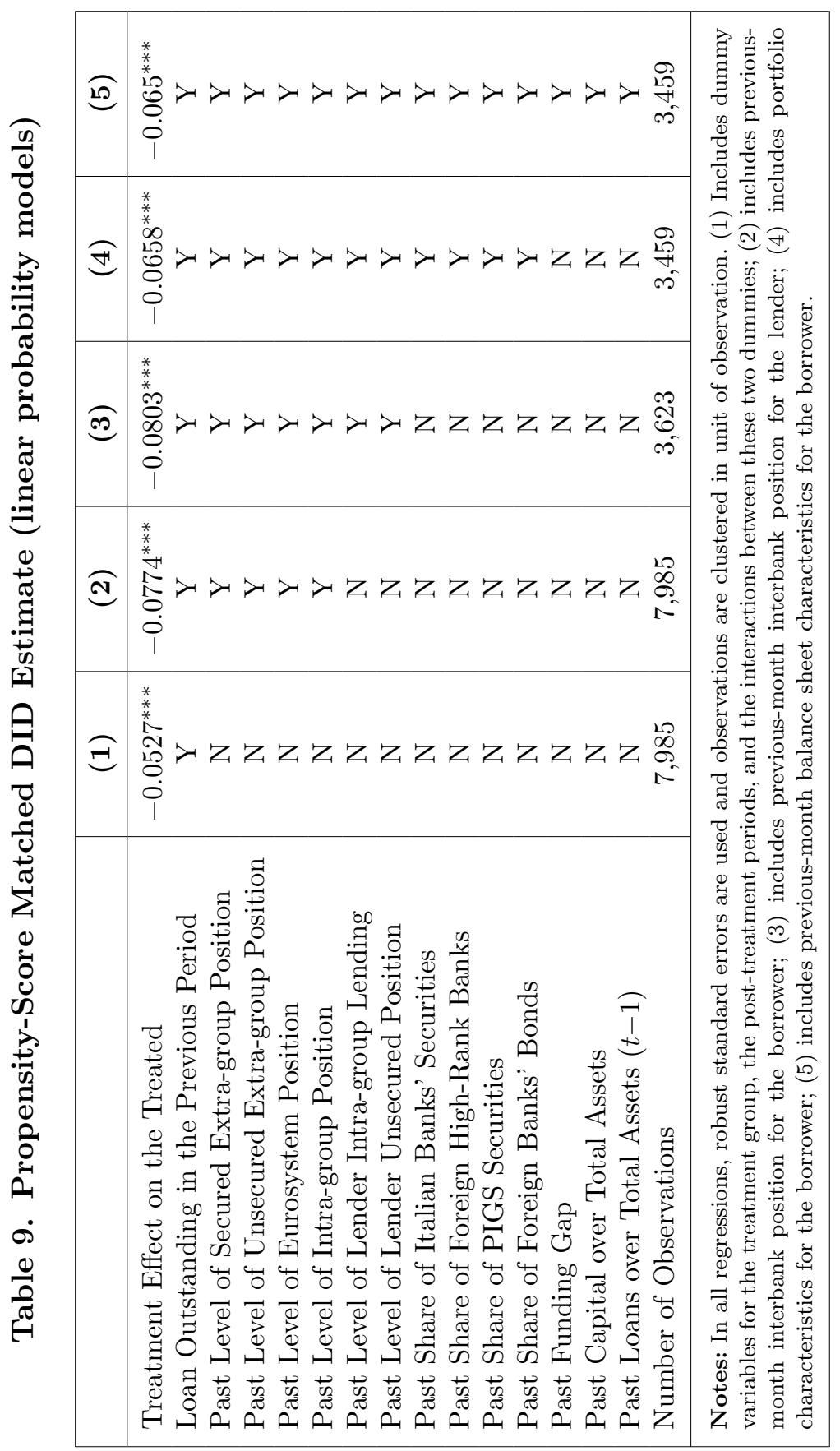




\begin{tabular}{|c|c|c|}
\hline$\sqrt{5}$ & 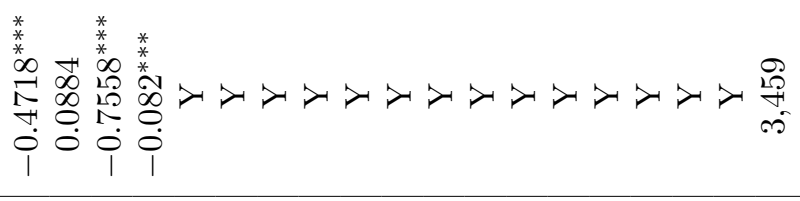 & 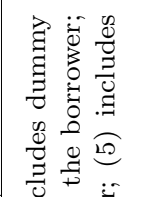 \\
\hline$\nexists$ & 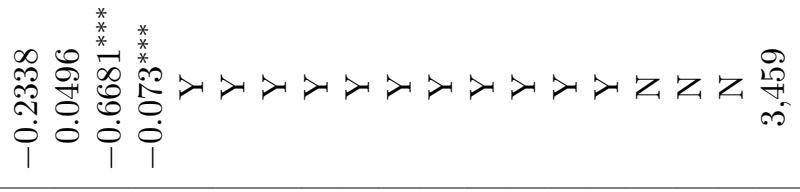 & 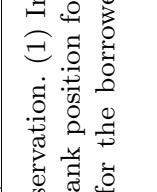 \\
\hline (9) & 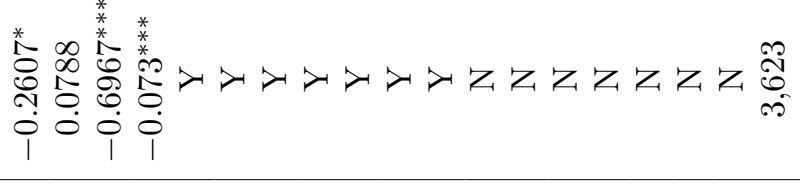 & 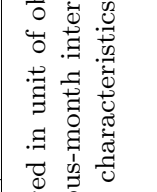 \\
\hline$\widehat{(a)}$ & 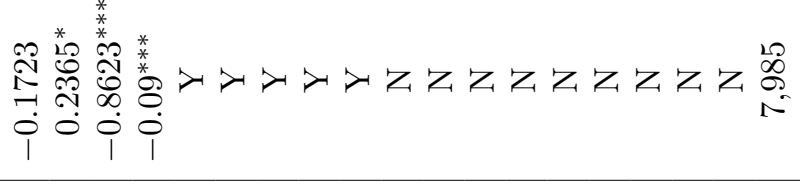 & $\begin{array}{l}9 \\
0\end{array}$ \\
\hline$\Xi$ & 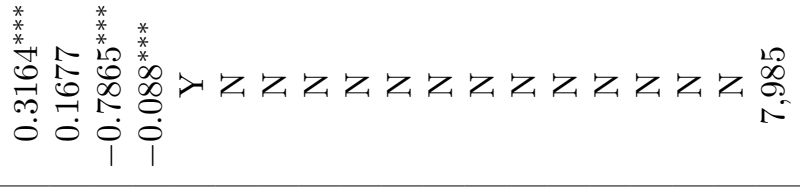 & \\
\hline & 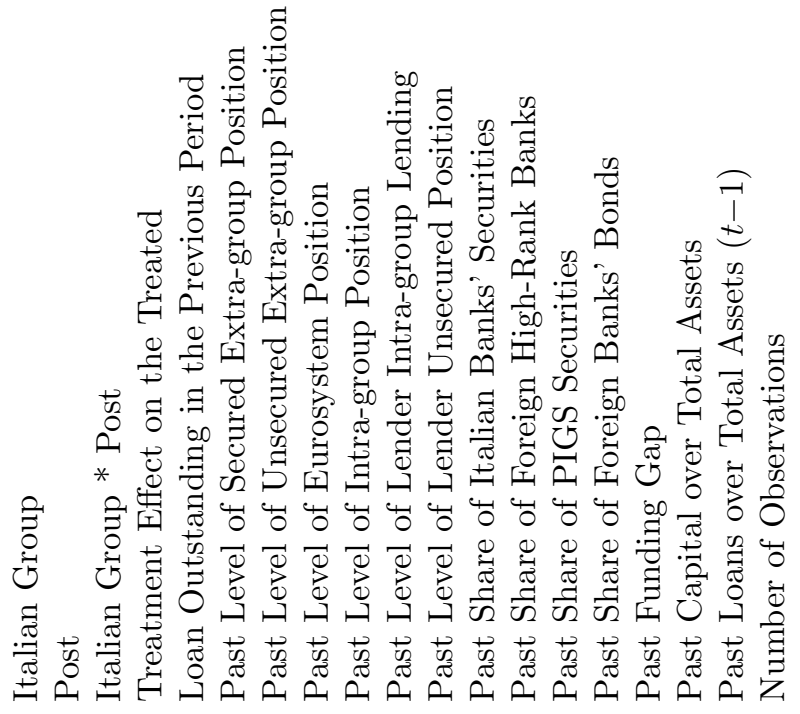 & 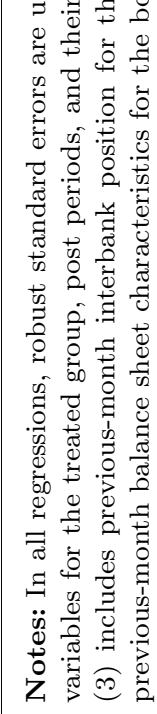 \\
\hline
\end{tabular}


Hence, we estimate a change-in-change model of the residuals of a linear probability model on the controls 19 This second specification, which delivers point estimates under weaker assumptions, also confirms that the probability of getting a loan from a foreign bank is significantly lower for Italian banks following the rise in counterparty risk (table 11) 20

As a final robustness check we focus our analysis on interbank loans within banks belonging to the same banking group. The probability of receiving loans for an Italian bank does not differ depending on whether the parent company is foreign or domestic. This evidence supports the intuitions that intra-group interbank loans were affected to a lesser extent by the increase in counterparty risk and they are less information sensitive (table 12).

\section{Conclusions}

This paper isolates and quantifies the effect of the increase in the riskiness of Italian banks during the sovereign debt crisis on their ability to borrow from foreign banks. Analyzing all borrowing positions of Italian banks vis-à-vis foreign banks in the unsecured interbank market between January 2011 and December 2011, we show how these borrowing positions changed following the sharp increase in Italian government bond yields (sovereign spreads). In this way we estimated the effects of counterparty risk alone on the functioning of interbank market, at least in the unsecured segment, which is more information sensitive.

Adopting a quasi-experimental methodology, we exploit the upsurge in Italian sovereign yields in July 2011 as an exogenous shock to counterparty risk. In fact, the sovereign crisis was fundamentally exogenous to the interbank market: both low growth and

\footnotetext{
${ }^{19}$ In order to guarantee the identification of the potential outcome for the treated group, the estimate must be conditional on realizations of characteristics that are in the common support of the treated and control groups before and after the treatment.

${ }^{20}$ As a further robustness check, we estimate the entire set of models using consolidated data (i.e., borrowing positions at group level) and only overnight positions. Again, the results support the hypothesis that the increase in counterparty risk significantly aggravated Italian banks' difficulty in obtaining funds from foreign banks.
} 


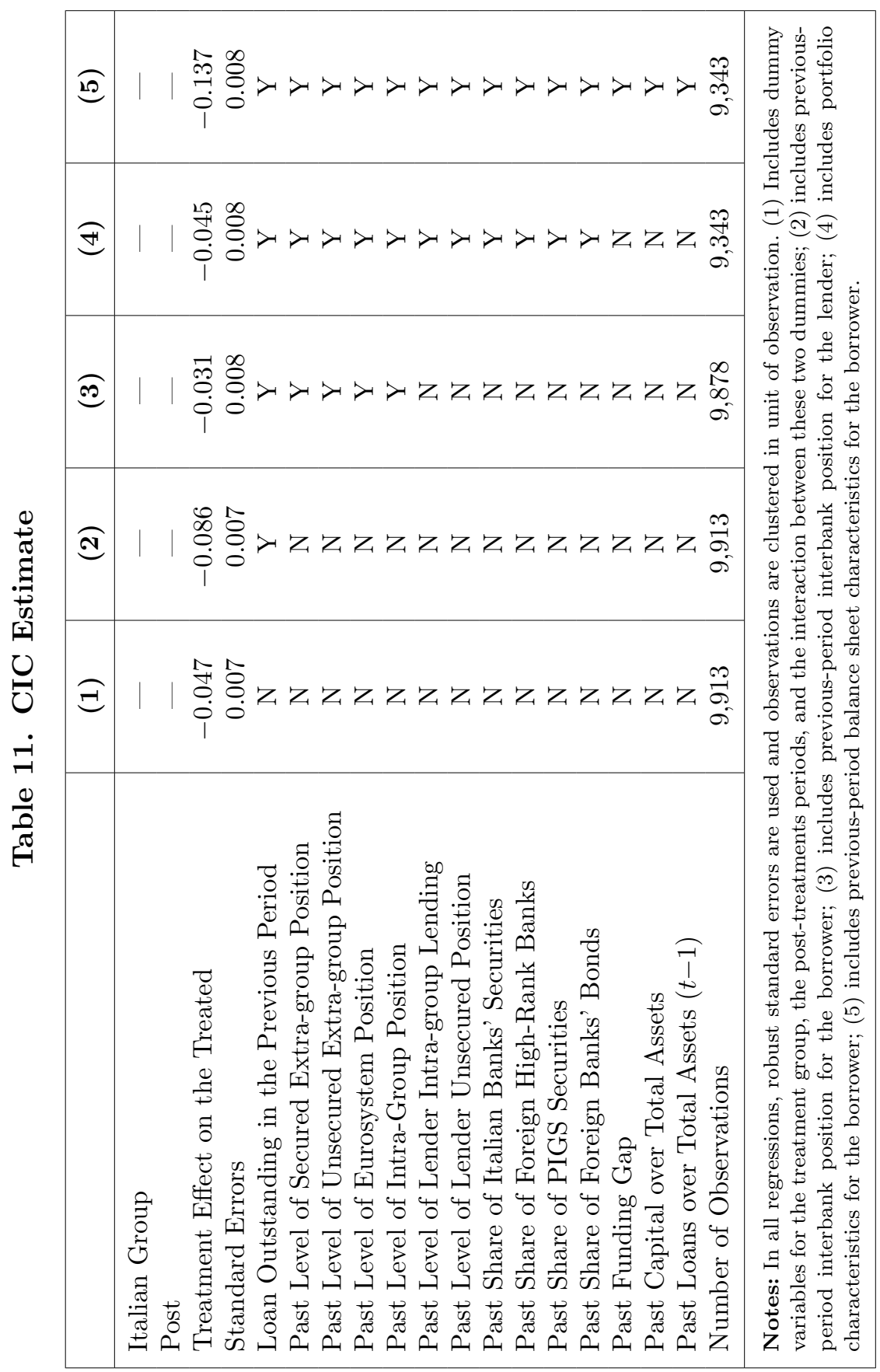




\begin{tabular}{|c|c|c|}
\hline (e) & 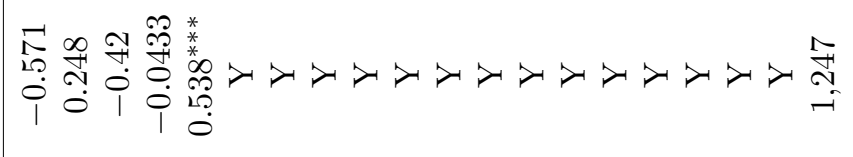 & 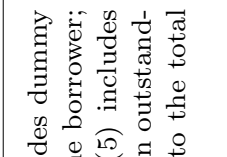 \\
\hline$\sqrt{10}$ & 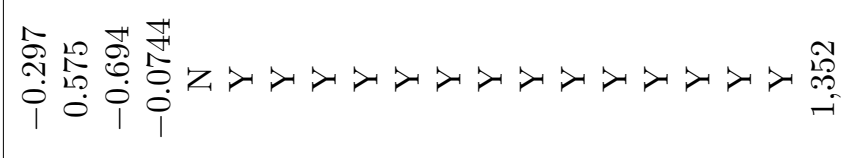 & 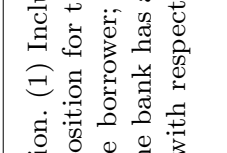 \\
\hline Fु & 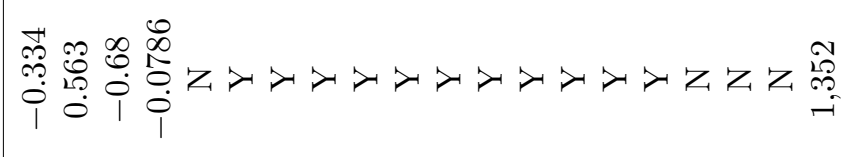 & \\
\hline$\widehat{(9)}$ & 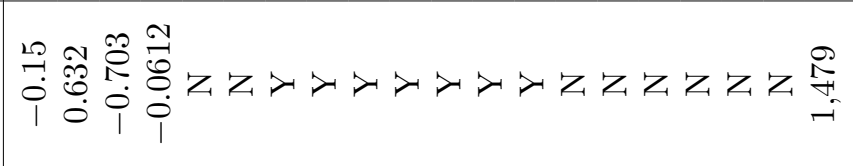 & $\begin{array}{l}a \\
0 \\
0 \\
0\end{array}$ \\
\hline$\widehat{\mathfrak{d}}$ & 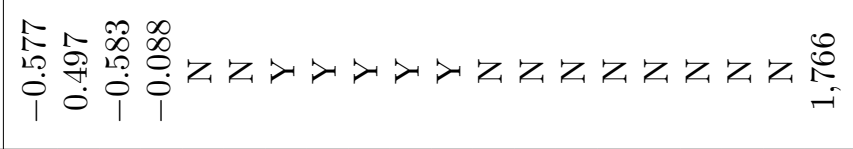 & \\
\hline$\Xi$ & 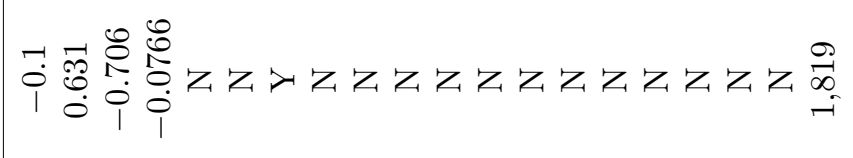 & \\
\hline & 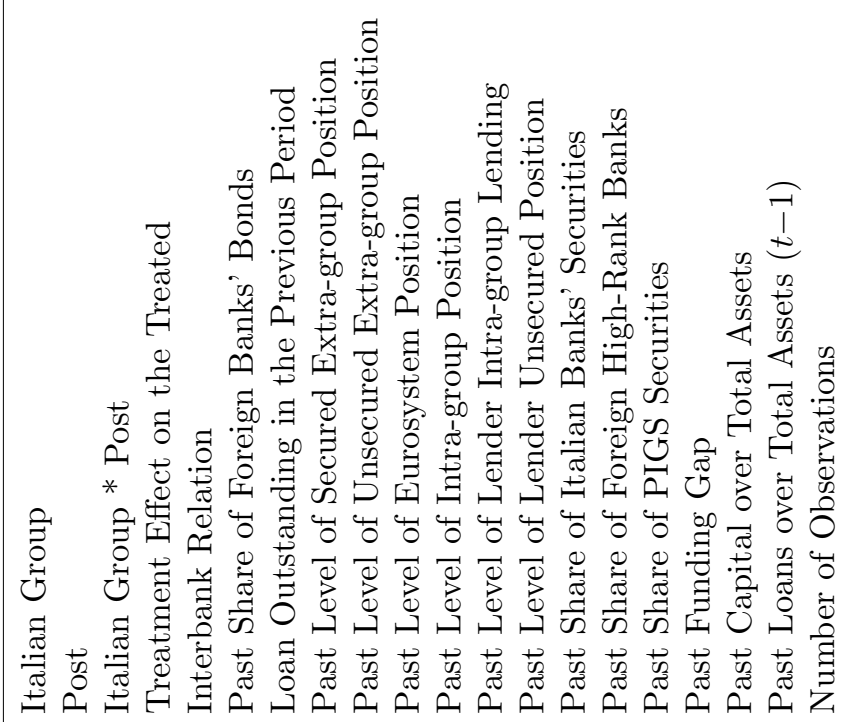 & $\begin{array}{l} \\
0\end{array}$ \\
\hline
\end{tabular}


high public debt are long-standing features of the Italian economy, and the interbank market was not a direct source of instability for the public debt. To identify the effect of the heightening of counterparty risk, we compared the borrowing capacity of sets of banks that were affected differentially by the crisis. Foreign banks headquartered in countries where sovereign risk increased substantially less were relatively shielded from the impact of sovereign tensions compared with Italian banks.

We estimated a baseline model factoring in a set of lender and borrower characteristics: lender's interbank lending volumes, borrower's net and gross interbank positions on secured and unsecured markets, borrower's asset composition, and borrower's balance sheet characteristics.

We find that the effect was statistically significant and economically important. Following the crisis, the probability of an Italian bank receiving a loan from a foreign bank fell by 6 percentage points more than that of branches and subsidiaries of foreign banking groups. The effect rises to 12 points if the sample is restricted to lenders domiciled in the core euro-area countries. The effect is less pronounced for safer banks, i.e., the more strongly capitalized ones, and for those with more stable relations with foreign banks. As a robustness check, to allow for fundamental differences in business between Italian and foreign banks, we ran the same regression using only comparable banks, with no essential alteration of the results.

\section{References}

Abadie, A. 2005. "Semiparametric Difference-in-Differences Estimators." Review of Economic Studies 72 (1): 1-19.

Abadie, A., and G. W. Imbens. 2006. "Large Sample Properties of Matching Estimators for Average Treatment Effects." Econometrica 74 (1): 235-67.

Affinito, M. 2012. "Do Interbank Customer Relationships Exist? And How Did They Function in the Crisis? Learning from Italy." Journal of Banking $\&$ Finance 36 (12): 3163-84.

2013. "Central Bank Refinancing, Interbank Markets and the Hypothesis of Liquidity Hoarding: Evidence from a EuroArea Banking System." ECB Working Paper No. 1607. 
Afonso, G., A. Kovner, and A. Schoar. 2011. "Stressed, Not Frozen: The Federal Funds Market in the Financial Crisis." Journal of Finance 66 (4): 1109-39.

Ai, C., and E. C. Norton. 2003. "Interaction Terms in Logit and Probit Models." Economics Letters 80 (1): 123-29.

Albertazzi, U., T. Ropele, G. Sene, and F. Signoretti. 2012. "The Impact of the Sovereign Crisis on the Lending Activity of Italian Banks." Occasional Paper No. 133, Bank of Italy.

Allen, F., E. Carletti, and D. Gale. 2009. "Interbank Market Liquidity and Central Bank Intervention." Journal of Monetary Economics 56 (5): 639-52.

Athey, S., and G. W. Imbens. 2006. "Identification and Inference in Nonlinear Difference-in-Differences Models." Econometrica 74 (2): 431-97.

Becker, S. O., and A. Ichino. 2002. "Estimation of Average Treatment Effects Based on Propensity Scores." Stata Journal 2 (4): 358-77.

Bofondi, M., L. Carpinelli, and E. Sette. 2013. "Credit Supply during a Sovereign Debt Crisis." Temi di discussione (Working Paper) No. 909, Bank of Italy.

Brunnermeier, M. K. 2009. "Deciphering the Liquidity and Credit Crunch 2007-2008." Journal of Economic Perspectives 23 (1): $77-100$.

Caliendo, M., and S. Kopeinig. 2008. "Some Practical Guidance for the Implementation of Propensity Score Matching." Journal of Economic Surveys 22 (1): 31-72.

Cappelletti, G., A. De Socio, G. Guazzarotti, and E. Mallucci. 2011. "The Impact of the Financial Crisis on Inter-Bank Funding: Evidence from Italian Balance Sheet Data." Occasional Paper No. 95, Bank of Italy.

Cassola, N., C. Holthausen, and F. Würtz. 2008. "Liquidity Management under Market Turmoil: Experience of the European Central Bank in the First Year of the 2007-2008 Financial Market Crisis." In The First Credit Market Turmoil of the 21st Century, ed. D. D. Evanoff, P. Hartmann, and G. G. Kaufman. World Scientific Studies in International Economics, Vol. 10, 195-228. New Jersey: World Scientific Publishing Co. 
Cocco, J. F., F. J. Gomes, and N. C. Martins. 2009. "Lending Relationships in the Interbank Market." Journal of Financial Intermediation 18 (1): 24-48.

Freixas, X., and C. Holthausen. 2005. "Interbank Market Integration under Asymmetric Information." Review of Financial Studies 18 (2): 459-90.

Furfine, C. H. 2001. "Banks as Monitors of Other Banks: Evidence from the Overnight Federal Funds Market." Journal of Business 74 (1): $33-58$.

Heider, F., M. Hoerova, and C. Holthausen. 2009. "Liquidity Hoarding and Interbank Market Spreads: The Role of Counterparty Risk." ECB Working Paper No. 1136.

Imbens, G. W., and J. M. Wooldridge. 2009. "Recent Developments in the Econometrics of Program Evaluation." Journal of Economic Literature 47 (1): 5-86.

International Monetary Fund. 2010. "Italy: 2010 Article IV Consultation-Staff Report."

Karas, A., K. J. Schoors, and G. Lanine. 2008. "Liquidity Matters: Evidence from the Russian Interbank Market." Mimeo.

Lechner, M. 2011. "The Estimation of Causal Effects by Differencein-Difference Methods." Discussion Paper No. 2010-28, Universitat St. Gallen.

Lee, S., and A. M. Shaikh. 2013. "Multiple Testing and Heterogeneous Treatment Effects: Re-evaluating the Effect of PROGRESA on School Enrollment." Journal of Applied Econometrics 29 (4): $612-26$.

Leuven, E., and B. Sianesi. 2003. "PSMATCH2: Stata Module to Perform Full Mahalanobis and Propensity Score Matching, Common Sport Graphing, and Covariate Imbalance Testing." Available at http://ideas.repec.org/c/boc/bocode/s432001.html.

Manna, M., and A. Schiavone. 2012. "Externalities in Interbank Network: Results from a Dynamic Simulation Model." Temi di Discussione (Working Paper) No. 893, Bank of Italy.

Mistrulli, P. 2011. "Assessing Financial Contagion in the Interbank Market: Maximum Entropy versus Observed Interbank Lending Patterns." Journal of Banking \& Finance 35 (5): 1114-27.

Panetta, F., et al. 2011. "The Impact of Sovereign Credit Risk on Bank Funding Conditions." CGFS Paper No. 43. 
Puhani, P. A. 2012. "The Treatment Effect, the Cross Difference, and the Interaction Term in Nonlinear "Difference-in-Differences" Models." Economic Letters 115 (1): 85-87.

Rochet, J. C., and J. Tirole. 1996. "Interbank Lending and Systemic Risk." Journal of Money, Credit and Banking 28 (4): 733-62.

Rosenbaum, P. R., and D. B. Rubin. 1983. "The Central Role of the Propensity Score in Observational Studies for Causal Effects. Biometrika 1 (70): 41-55.

Upper, C. 2011. "Simulation Methods to Assess the Danger of Contagion in Interbank Markets." Journal of Financial Stability 7 (3): 111-25. 